\title{
A new species of Bryophryne (Anura: Strabomantidae) from the Cordillera de Vilcabamba, southeastern Peruvian Andes
}

\author{
Luis Mamani, ${ }^{1,2,3}$ Alessandro Catenazzi, ${ }^{4}$ Alex Ttito,,${ }^{1,2}$ Sergio Mallqui, ${ }^{1,2}$ and Juan C. Chaparro ${ }^{1,2}$ \\ ${ }^{1}$ Museo de Historia Natural de la Universidad Nacional de San Antonio Abad del Cusco (MHNC), Colección de Herpetología, \\ Paraninfo Universitario S/N (Plaza de Armas), Cusco, Peru. E-mail: luismamanic@ gmail.com. \\ ${ }^{2}$ Museo de Biodiversidad del Perú (MUBI), Urbanización Mariscal Gamarra A-61, Zona 2, Cusco, Peru. E-mail: jchaparroauza@ \\ yahoo.com. \\ ${ }^{3}$ Programa de Magister en Ciencias con mención en Zoología, Departamento de Zoología, Facultad de Ciencias Naturales y \\ Oceanográficas, Universidad de Concepción, Barrio Universitario s/n, Casilla 160C, Concepción, Chile. \\ ${ }^{4}$ Department of Zoology, Southern Illinois University Carbondale, Carbondale, USA. E-mail: acatenazzi@gmail.com.
}

\begin{abstract}
A new species of Bryophryne (Anura: Strabomantidae) from the Cordillera de Vilcabamba, southeastern Peruvian Andes. We describe a new species of Bryophryne from the Cordillera de Vilcabamba in Department Cusco, in the southeastern Peruvian Andes. The new species differs from all other congeneric taxa, except B. flammiventris and B. gymnotis, by possessing a weakly defined tympanic membrane and tympanic annulus, by the presence of vocal sac and vocal slits in males, and by producing advertisement calls. The new species is distinguished from B. flammiventris and B. gymnotis by skin texture, presence of small, oblique dentigerous processes on the vomer, ventral coloration ranging from bluish-gray to whitish-gray with irregular or reticulate dark brown spots, and call composed of two or three notes. The new species is further characterized by having dorsal skin shagreen with tubercles, discontinuous dorsolateral folds, skin smooth on ventral surfaces of the body, and lateral fringes on fingers and toes. This species was found at the transition from montane forest to high Andean puna, where it occurs in moist microhabitats under moss and rocks at elevations from 3519 to $3707 \mathrm{~m}$ a.s.l.
\end{abstract}

Keywords: amphibians, Brachycephaloidea, Choquequirao Archeological Complex, humid grassland, Terrarana. 


\begin{abstract}
Resumen
Una nueva especie de Bryophryne (Anura: Strabomantidae) de la Cordillera de Vilcabamba, sudeste de los Andes peruanos. Describimos una nueva especie de Bryophryne proveniente de la Cordillera de Vilcabamba, en el Departamento de Cusco, en los Andes del sureste de Perú. La nueva especie se diferencia de las demás especies de Bryophryne, excepto por B. flammiventris y $B$. gymnotis, por tener membrana y anillo timpánico poco definidos, machos con sacos y hendiduras vocales, y por emitir llamados nupciales; además, se diferencia de B. flammiventris y B. gymnotis por la textura de su piel, la presencia de procesos vomerianos pequeños y oblicuos, coloración ventral gris azulada a gris clara con manchas marrones irregulares o reticuladas, y llamado nupcial compuesto por dos o tres notas. Los especímenes de la nueva especie se caracterizan además por tener piel dorsal finamente granulada con tubérculos, pliegues dorsolaterales discontinuos, piel lisa en partes ventrales, y presencia de quillas laterales en los dedos de manos y pies. Esta especie habita los bosques altoandinos, entre la puna y el bosque montano, y fue encontrada en ambientes húmedos entre musgo y bajo piedras a elevaciones de 3519 a 3707 m s.n.m.
\end{abstract}

Palabras clave: anfibios, Brachycephaloidea, Complejo Arquelógico de Choquequirao, pastizales húmedos, Terrarana.

\begin{abstract}
Resumo
Uma nova espécie de Bryophryne (Anura: Strabomantidae) da Cordilheira de Vilcabamba, sudeste dos Andes peruanos. Descrevemos uma nova espécie de Bryophryne proveniente da Cordilheira de Vilcabamba, Departamento de Cusco, nos Andes do sudeste do Peru. A nova espécie se diferencia das demais espécies do gênero, excepto de B. flammiventris e de B. gymnotis, por apresentar membrana e anel timpânicos pouco definidos, machos com sacos e fendas vocais e por emitir cantos nupciais; além disso, diferencia-se de B. flammiventris e de B. gymnotis pela textura da pele, presença de processos vomerianos pequenos e oblíquos, coloração ventral cinza azulado a cinza claro com manchas marrons irregulares ou reticuladas e canto nupcial composto por duas ou três notas. Os espécimes da nova espécie caracterizam-se ainda pela pele dorsal finamente granulada com tubérculos, pregas dorso-laterais descontínuas, pele lisa nas partes ventrais e presença de quilhas laterais nos dedos das mãos e dos pés. Esta espécie habita os bosques altoandinos, entre a puna e o bosque montano, e foi encontrada em ambientes úmidos entre musgos e debaixo de pedras em altitudes de 3519 a $3707 \mathrm{~m}$ acima do nível do mar.
\end{abstract}

Palavras-chave: anfíbios, Brachycephaloidea, campos úmidos, Complexo Arqueológico de Choquequirao, Terrarana.

\section{Introduction}

The genus Bryophryne Hedges, Duellman and Heinicke, 2008 is a group of small frogs endemic to the high Andes of the Peruvian department of Cusco and Puno, where they inhabit the montane forest, montane cloud forest, and wet puna from 2350-4120 m a.s.l. (Chaparro et al. 2007, 2015, Lehr and Catenazzi 2008, 2009, 2010, Duellman and Lehr 2009). Hedges et al. (2008), based on molecular data, proposed the monophyly of the genus and allocated it to the subfamily Holoadeninae; $B$. cophites was designated as the type species. Subsequently, the monophyletic status of the genus was corroborated by Chaparro et al. (2015), De la Riva et al. (2017), Heinicke et al. (2017), and Padial et al. (2014).

Molecular evidence and distribution patterns have been strongly decisive in designation of new species and regrouping lineages (Hedges et al. 2008, Padial et al. 2012, Chaparro et al. 2015, De la Riva et al. 2017). Based on this evidence, the existence of three sympatric species of 
Bryophryne by mountain pass has been proposed (Lehr \& Catenazzi 2008, 2009). A linear distance of $50 \mathrm{~km}$ is sufficient for species divergence (Catenazzi et al. 2017). The isolation of species of Bryophryne could be explained by geomorphology of the Andes (allopatric speciation), climatic variables, low vagility and semifossorial habits, or by productivity of their environment, which is sufficient to maintain the requirements of their small bodies.

The diversity of high Andean Terrarana has been underestimated. Recent expeditions and published manuscripts show clear evidence of high beta diversity in the eastern slopes of the Peruvian and Bolivian Andes (De la Riva et al. 2017, Rodriguez and Catenazzi 2017). Most species of Bryophryne have been discovered in the last decade (Chaparro et al. 2007, 2015, Lehr and Catenazzi 2008, 2009, 2010, Catenazzi et al. 2017, De la Riva et al. 2017), increasing the current number to 13 species. Recent field work in the Archeological Complex of Choquequirao, Departamento Cusco has uncovered previously unknown species of Holoadeninae. Here we describe one of these new frogs, the third species of Bryophryne possessing a tympanic membrane and annulus and known to produce an advertisement call.

\section{Materials and Methods}

All specimens were collected by hand, fixed in $10 \%$ formalin and preserved in $70 \%$ ethanol. Terminology for diagnostic characters and format description follows Duellman and Lehr (2009) and Lynch and Duellman (1997). Measurements were taken with a digital caliper to the nearest $0.01 \mathrm{~mm}$ and rounded to 0.1 to avoid pseudo-precision. Abbreviations for measurements are as follows: SVL (snout-vent length), HL (head length, from posterior margin of jaw to tip of snout), HW (maximum width of head), EL (eye length, measured horizontally), EN (eye to nostril distance), IND (internarial distance), ED (eye diameter horizontal), IOD (interorbital distance), EW (eyelid width), TL (tibia length), and FL (foot length, distance from posterior margin of inner metatarsal tubercle to tip of fourth toe). We determined comparative lengths of Toes III and V by adpressing both toes against Toe IV; lengths of Fingers I and II were determined by adpressing these fingers against each other. Sexual condition was determined through morphologic external characters, dissection, and examination of ovarian condition. Comparisons of diagnostic characters are based on species descriptions found in the literature (Chaparro et al. 2007, 2015, Hedges et al. 2008, Lehr and Catenazzi 2008, 2009, 2010, Catenazzi et al. 2017) and the examination of type and referred specimens. Specimens examined are listed in Appendix I; Natural History Museum acronyms are: CORBIDI = Herpetology Collection, Centro de Ornitología y Biodiversidad, Lima, Peru; MUBI = Museo de Biodiversidad del Perú, Cusco; KU = Natural History Museum, The University of Kansas, Lawrence, Kansas, USA; MUSM = Museo de Historia Natural Universidad Nacional Mayor de San Marcos, Lima, Peru; MHNG = Muséum d'Histoire Naturelle, Genève, Switzerland; MTD = Museum für Tierkunde Dresden.

We recorded an unvouchered specimen at the type locality at 10:40 hrs on 20 September 2016 $\left(\mathrm{T}_{\text {air }}=13.3^{\circ} \mathrm{C}\right)$, along with several unvouchered males, with a digital recorder (Marantz PMD660; WAV format, $44 \mathrm{KHz}, 24$ bit). We used Raven Pro, version 1.4 (Cornell Laboratory of Ornithology, Ithaca, NY) to analyze call variables. We analyzed a total of three calls. The following variables were measured from oscillograms: note duration and rate, interval between notes or calls, number of pulses, and presence of amplitude modulation (Lehr and Catenazzi 2009). Variables measured from spectrograms included dominant frequency, and presence of frequency modulation or harmonics. Spectral parameters were calculated through fast Fourier transform (FFT) set at a length of 512 points (Hann window, 50\% overlap). Averages are reported $\pm \mathrm{SD}$. 
Coloration in life is based on field notes and photographs taken by LM using a Canon 550D digital camera with a Canon $100 \mathrm{~mm}$ macro lens.

\section{Results}

\section{Bryophryne mancoinca sp. nov.} (Figures 1 and 2A, B)

Holotype.-MUBI 11152, an adult female (Figures 1, 2A, B) from Hornopampa sector, near Salkantay Mountain, along the road to the Archeological Complex of Choquequirao, 3707 m a.s.l., $\left(13^{\circ} 18^{\prime} 26^{\prime \prime} \mathrm{S}, 72^{\circ} 44^{\prime} 90^{\prime \prime} \mathrm{W}\right)$, Distrito Santa Teresa, Provincia La Convención, Departamento Cusco, Peru, collected by Luis Mamani and Federico Argandoña on 16 September 2011.

Paratypes.-Twelve specimens: Seven adult males: MUBI 11147, 11148, 11149 (Figure 2C, D), 11150 (Figure 2E, F), 11151, 11153 (Figure $2 \mathrm{G}, \mathrm{H})$, and 11154; and one juvenile female: MUBI 11159, all from the type locality; three adult females: MUBI 16068 (Figure 2I, J), 16069 (Figure 2K, L), 16074; one juvenile male, MUBI 16083, all from Hornopampa, near Salkantay Mountain, along the road to the Archeological Complex of Choquequirao, 3519 m a.s.l., (13¹9'17" S, 72 43'93" W), Distrito Santa Teresa, Provincia La Convención, Departamento Cusco, Peru, collected by Luis Mamani, Alex Ttito and Sergio Mallqui on 19 September 2015.

Generic placement.-The new species is assigned to the genus Bryophryne Hedges et al. (2008) on the basis of its general appearance (chubby body, short legs and arms), which matches that of other species placed in this genus, and its occurrence southeast of the Apurimac River valley (Lehr and Catenazzi 2008, 2009, 2010, Chaparro et al. 2015). Although most species of Bryophryne lack the tympanic membrane and annulus, $B$. flammiventris Lehr and Catenazzi, 2010 and $B$. gymnotis Lehr and Catenazzi, 2009 possess both characters and are likely closely related to $B$. mancoinca sp. nov. (see diagnosis and comments in Discussion).

Diagnosis.-The new species is characterized by: (1) skin on dorsum shagreen with small, conical tubercles; dorsolateral folds continuous only along anterior half of dorsum; skin of venter, throat and chest smooth; discoidal fold present; thoracic fold present; (2) tympanic membrane and tympanic annulus weakly defined; (3) snout short, rounded in dorsal and lateral views; (4) upper eyelid with small tubercles; cranial crests absent; (5) dentigerous processes of vomers small, oblique; vomerine teeth absent; (6) vocal sac and slits present, nuptial pad absent; (7) Finger I slightly shorter than Finger II; tips of fingers rounded; (8) fingers with lateral fringes; (9) ulnar tubercles and tarsal tubercles present, small; (10) heel with small tubercle; tarsal fold absent; (11) inner metatarsal tubercle ovoid, 1.5 times larger than outer; supernumerary plantar tubercles numerous and low, not visible in preservative; palmar tubercle slightly ovoid, thenar tubercle ovoid; supernumerary palmar tubercles few and scattered; (12) toes having lateral fringes; basal webbing present between toes III and IV; Toe V shorter than Toe III; toe tips rounded; (13) in life, dorsal coloration reddish-brown, or grayish-brown, with narrow tan middorsal stripe; ventral coloration gray, or pale bluish-gray with reddish-brown reticulation, throat and chest brown or dark brown; (14) SVL in adult females $23.6-26.5 \mathrm{~mm}(N=4)$, in males 19.6-22.9 mm $(N=2)$ (Table 1).

Bryophryne mancoinca sp. nov. is readily distinguished from all other species of Bryophryne, except for B. flammiventris, $B$. gymnotis, B. quellokunka, B. tocra, and B. wilakunka, by the presence of a tympanic membrane and tympanic annulus. Bryophryne mancoinca sp. nov. differs (characteristics of other species in parentheses) from $B$. flammiventris by having ventral skin smooth 

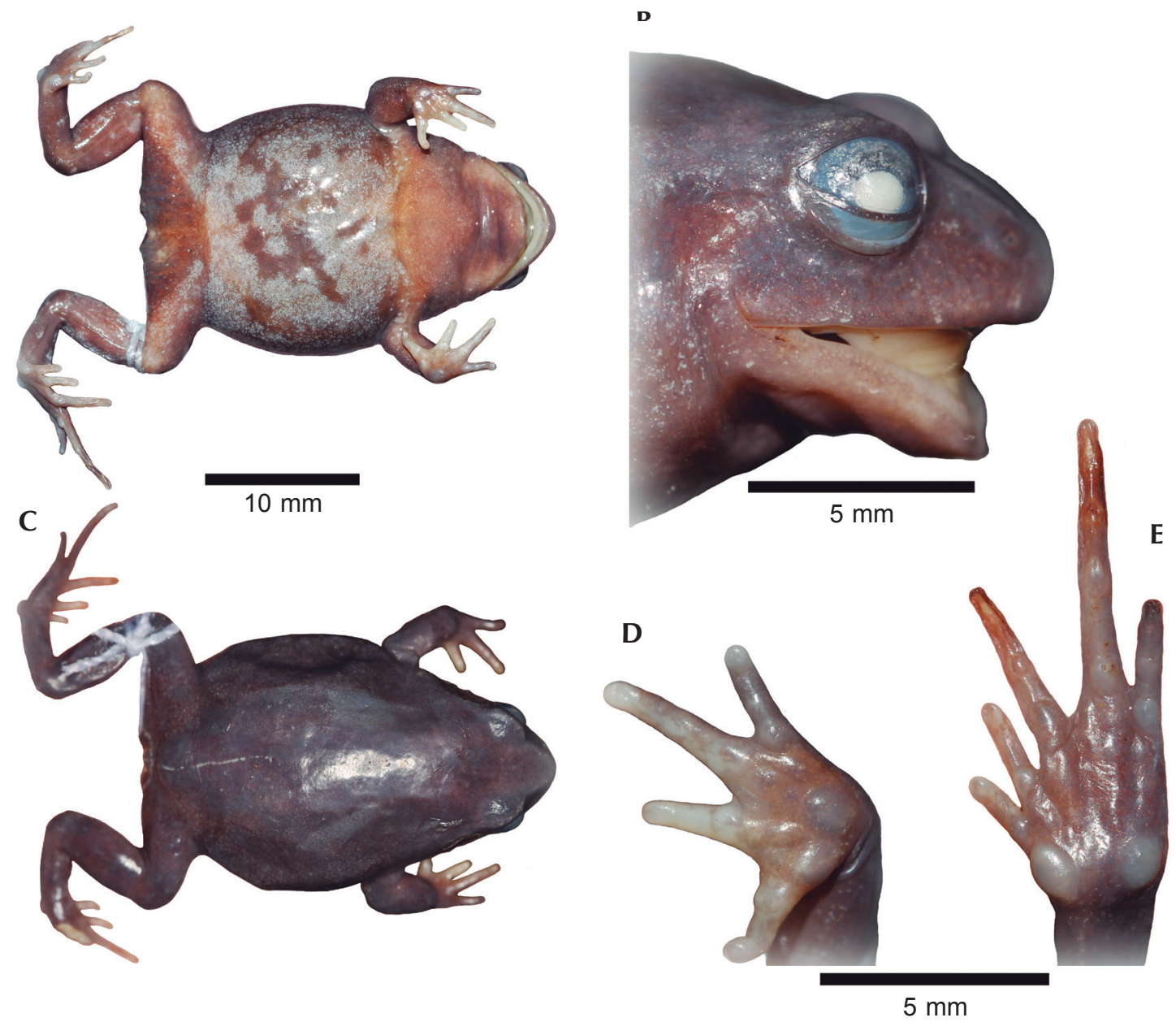

Figure 1. (A) Dorsal, (B) ventral, (C) lateral views of the head, (D) hand, and (E) foot of the adult female holotype of Bryophryne mancoinca sp. nov. (MUBI 11152).

(weakly areolate), dentigerous processes of vomer small and oblique (absent), ventral coloration gray with reddish-brown reticulation (black with yellow, orange or pink blotches). Bryophryne mancoinca sp. nov. differs from $B$. gymnotis (characteristics of $B$. gymnotis in parentheses) by having skin on dorsum shagreen with tubercles (without tubercles), discoidal fold present (absent), dentigerous processes of vomers small and oblique (rounded), ventral coloration gray with reddish-brown reticulation (dark brown or reddish-brown with pale gray flecks), and advertisement call composed of three notes with fundamental frequency of $2400 \mathrm{~Hz}$ (single note, $3010 \mathrm{~Hz}$ ). The new species differs from $B$. quellokunka by having ventral skin smooth (weakly areolate), dentigerous processes of vomer present (absent). It differs from $B$. tocra and $B$. wilakunka by having ventral skin smooth (areolate) and dentigerous processes of vomer present (absent). 

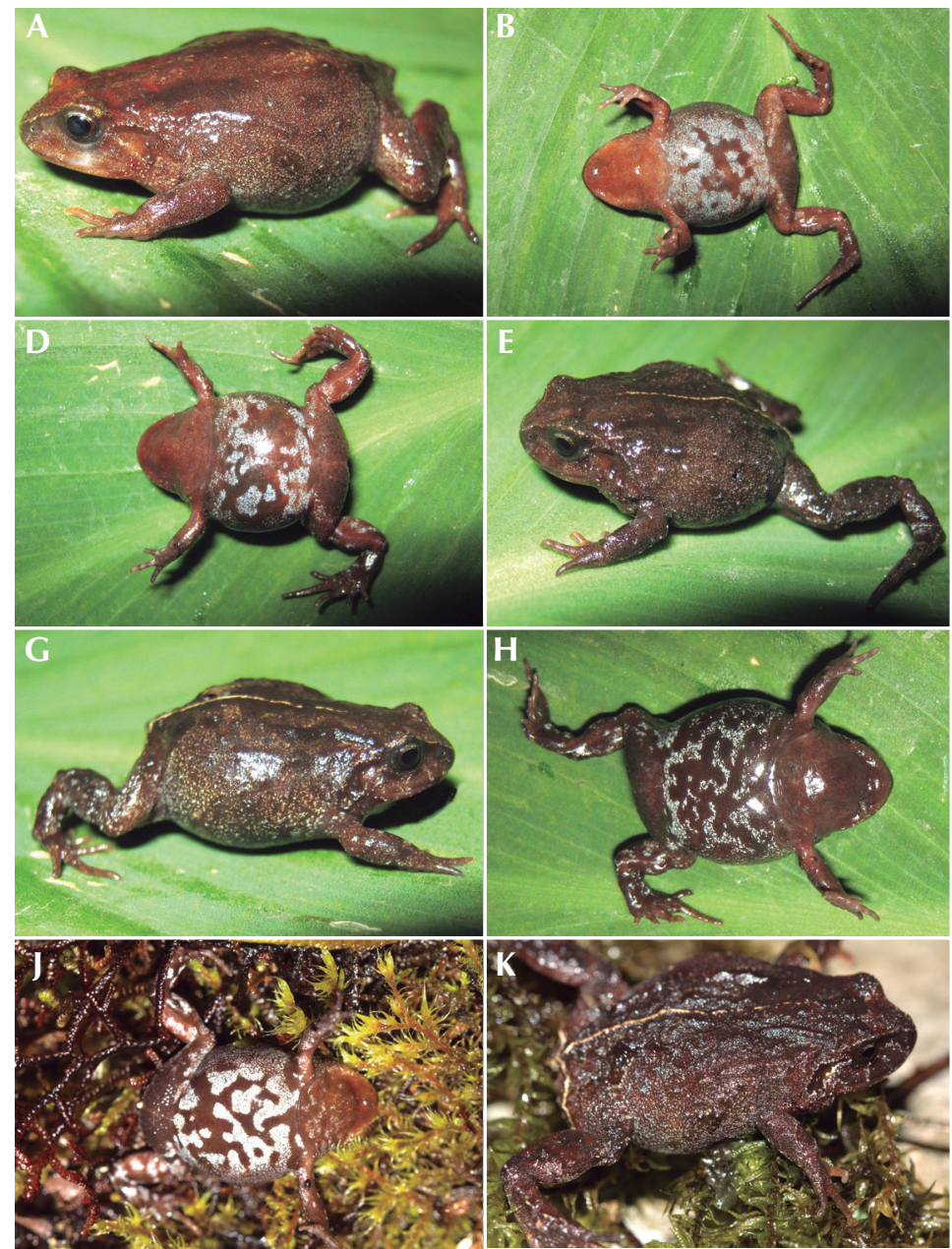
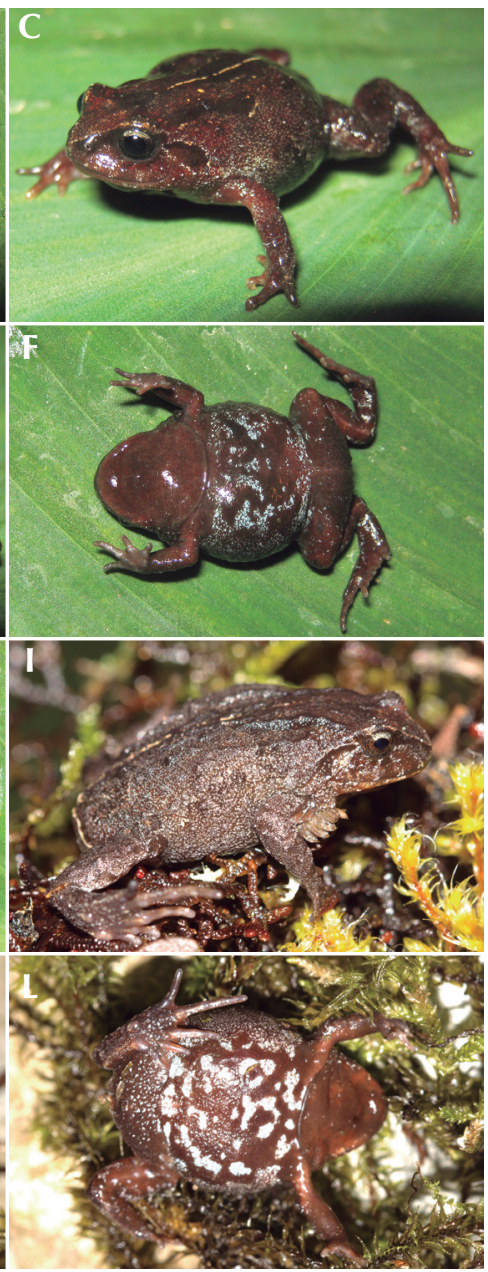

Figure 2. Dorsal and ventral views of adult Bryophryne mancoinca sp. nov. A-B, female (MUBI 1152, Holotype); C-D, male (MUBI 11149); E-F, male (MUBI 11150); G-H, male (MUBI 11153); I-J, female (MUBI 16069); and K-L, female (MUBI 16069). Photos by Luis Mamani.

Description of the holotype.-Adult female; body robust; skin on dorsum and flanks shagreen with small, conical tubercles; dorsolateral folds discontinuous (continuous only from head to point of arm insertion to mid dorsum); ventral skin smooth; throat, chest, and belly smooth; discoidal fold present, thoracic fold weak; head narrower than body, wider than long; head width $35 \%$ of SVL; head length $26 \%$ of SVL; snout short, rounded in dorsal and lateral view (Figure
1); canthus rostralis slightly convex in profile and dorsal view; loreal region slightly convex; lips rounded; upper eyelid without enlarged tubercles; nostril lateral, weakly protuberant; eye-nostril distance $69 \%$ of eye length; interorbital region flat, cranial crests absent; tympanic membrane and tympanic annulus present and weakly defined; supratympanic fold an elliptical arc, extending from posterior corner of eye to half distance between eyes and insertion 


\begin{tabular}{|c|c|c|c|c|c|c|c|c|c|c|c|c|}
\hline 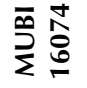 & 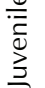 & సֶ. & $\stackrel{+}{0}$ & $\hat{\curvearrowright}$ & 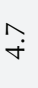 & 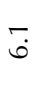 & $\stackrel{\rho}{-}$ & $\stackrel{n}{i}$ & ب. & $\stackrel{\rho}{-}$ & $\stackrel{+}{\longrightarrow}$ & $\stackrel{\circ}{\longrightarrow}$ \\
\hline $\begin{array}{l}\bar{\rho} \\
\bar{\Sigma} \\
\Sigma\end{array}$ & $\begin{array}{l}\frac{\vec{\sigma}}{\tilde{\sigma}} \\
\frac{\bar{\sigma}}{\sqcup}\end{array}$ & $\stackrel{\circ}{\stackrel{\dot{\nu}}{ }}$ & $\begin{array}{l}\hat{\infty} \\
\infty\end{array}$ & $\stackrel{\Upsilon}{\simeq}$ & 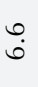 & $\begin{array}{l}\infty \\
\infty \\
\infty\end{array}$ & $\stackrel{+}{i}$ & $\stackrel{\llcorner}{\sim}$ & 亦 & $\stackrel{+}{\mathrm{i}}$ & $\stackrel{\circ}{i}$ & $\stackrel{m}{-}$ \\
\hline 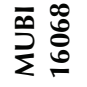 & $\begin{array}{l}\frac{0}{\sqrt{\sigma}} \\
\frac{\tilde{\varepsilon}}{4}\end{array}$ & 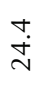 & $\stackrel{0}{0}_{\infty}^{\circ}$ & $\stackrel{\stackrel{\leftrightarrow}{\circ}}{\circ}$ & تَ & $\begin{array}{l}\infty \\
\infty \\
\infty \\
\infty\end{array}$ & $\stackrel{n}{i}$ & $\stackrel{\nabla}{i}$ & $\stackrel{\infty}{\longrightarrow}$ & $\stackrel{\stackrel{\leftrightarrow}{i}}{\stackrel{r}{*}}$ & $\stackrel{0}{i}$ & $\stackrel{\Upsilon}{=}$ \\
\hline 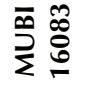 & 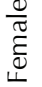 & $\begin{array}{l}\dot{0} \\
\ddot{v}\end{array}$ & $\underset{\infty}{N}$ & $\stackrel{n ?}{\circ}$ & ఇ̧ & $\overbrace{\infty}^{+}$ & $\underset{\sim}{ָ}$ & $\stackrel{\nabla}{\sim}$ & $\stackrel{?}{\longrightarrow}$ & 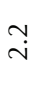 & 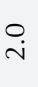 & $\stackrel{N}{\longrightarrow}$ \\
\hline 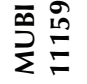 & $\begin{array}{l}\frac{0}{\pi} \\
\frac{\pi}{\tilde{\sigma}} \\
\end{array}$ & 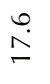 & $\stackrel{\circ}{\wedge}$ & $\bar{\infty}^{\circ}$ & $\stackrel{⿱ ⺌}{i}$ & 过 & $\overline{\mathrm{i}}$ & $\stackrel{\rho}{r}$ & $\stackrel{0}{-}$ & $\stackrel{\sigma}{-}$ & $\stackrel{+}{-}$ & $\stackrel{\circ}{-}$ \\
\hline 总全 & $\frac{0}{\frac{0}{2}}$ & $\begin{array}{l}\stackrel{0}{\circ} \\
\stackrel{\sigma}{\sigma}\end{array}$ & $\stackrel{n}{n}$ & $\stackrel{\widehat{\infty}}{\widehat{\infty}}$ & $\stackrel{⿱ ⺌}{\text { in }}$ & $\stackrel{n ?}{\sim}$ & $\stackrel{m}{i}$ & $\bar{i}$ & 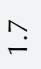 & $\stackrel{\circ}{i}$ & بִ & $\check{\ulcorner}$ \\
\hline 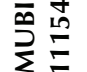 & $\frac{0}{\frac{0}{2}}$ & $\frac{\dot{\sim}}{\sim}$ & $\stackrel{\stackrel{\leftrightarrow}{\wedge}}{ }$ & $\bar{\sigma}$ & o. & $\stackrel{\sigma}{\wedge}$ & $\stackrel{+}{\mathrm{i}}$ & $\stackrel{+}{\sim}$ & $\stackrel{?}{-}$ & $\bar{i}$ & $\stackrel{\text { }}{-}$ & 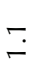 \\
\hline $\begin{array}{l}\bar{\rho} \\
\bar{\Sigma} \\
\bar{\Sigma}\end{array}$ & $\frac{0}{\frac{\pi}{\pi}}$ & $\begin{array}{l}\stackrel{0}{\mathbf{v}} \\
\vec{N}\end{array}$ & $\begin{array}{l}\circ \\
\infty\end{array}$ & 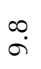 & ָु & $\infty$ & $\stackrel{m}{i}$ & $\stackrel{\stackrel{n}{i}}{i}$ & $\stackrel{?}{\longrightarrow}$ & $\bar{i}$ & $\stackrel{\text { }}{\underline{-}}$ & $\check{\square}$ \\
\hline $\begin{array}{l}\bar{\rho} \\
\stackrel{g}{g} \\
\stackrel{g}{\Sigma}\end{array}$ & $\frac{\frac{0}{\pi}}{\sum}$ & $\stackrel{\llcorner ?}{\bar{N}}$ & $\stackrel{\hat{n}}{\wedge}$ & $\tilde{\sigma}$ & ָु & $\stackrel{\sigma}{\sim}$ & $\stackrel{\nabla}{\stackrel{\sim}{*}}$ & $\stackrel{\leftrightarrow}{i}$ & $\stackrel{\infty}{-}$ & $\stackrel{\leftrightarrow}{i}$ & 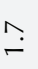 & $\stackrel{\Upsilon}{\longrightarrow}$ \\
\hline 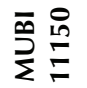 & $\frac{0}{\frac{0}{\pi}}$ & $\frac{\infty}{\grave{\nu}}$ & $\stackrel{a}{\wedge}$ & $\bar{\sigma}$ & $\overline{6}$ & $\bar{\infty}^{\circ}$ & 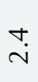 & $\stackrel{\vec{i}}{i}$ & $\stackrel{\Xi}{-}$ & $\bar{i}$ & 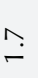 & $\stackrel{\sim}{\longrightarrow}$ \\
\hline 馬 & $\frac{\frac{0}{\pi}}{\sum^{\pi}}$ & $\stackrel{\tilde{N}}{\sim}$ & $\begin{array}{l}0 \\
\infty \\
\infty\end{array}$ & $\stackrel{\stackrel{\leftrightarrow}{\circ}}{\circ}$ & $\vec{\sigma}_{0}^{\circ}$ & $m_{\infty}^{\circ}$ & $\stackrel{m}{i}$ & $\stackrel{\nabla}{i}$ & $\stackrel{\text { }}{-}$ & $\bar{i}$ & $\stackrel{\circ}{i}$ & $\stackrel{m}{r}$ \\
\hline 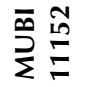 & $\begin{array}{l}\frac{0}{\widetilde{\sigma}} \\
\frac{\tilde{\varepsilon}}{4}\end{array}$ & 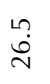 & $\begin{array}{l}a \\
\infty\end{array}$ & 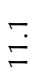 & $\stackrel{0}{\wedge}$ & $\sigma_{\sigma}^{\circ}$ & $\stackrel{\infty}{\stackrel{\infty}{N}}$ & 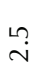 & $\stackrel{\rho}{-}$ & $\stackrel{+}{i}$ & $\stackrel{?}{?}$ & $\stackrel{m}{\sim}$ \\
\hline 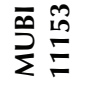 & $\frac{0}{\frac{\pi}{2}}$ & $\stackrel{\varrho}{\tilde{N}}$ & $\stackrel{\bullet}{\wedge}$ & $\begin{array}{l}\infty \\
\infty \\
\infty\end{array}$ & $\begin{array}{l}\infty \\
\stackrel{\infty}{\infty}\end{array}$ & $\stackrel{\sigma}{\wedge}$ & 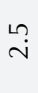 & $\stackrel{\sim}{\sim}$ & 冓 & ָָ & 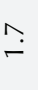 & 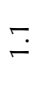 \\
\hline & & डे & $\vdash$ & $\vec{\psi}$ & $\overline{\underline{I}}$ & 王 & $\vec{\psi}$ & $\underline{0}$ & 点 & $\underline{\underline{z}}$ & Z & 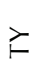 \\
\hline
\end{tabular}


of arm; tongue large, oval; choanae small, rounded; dentigerous processes of vomer small, oblique; limbs moderately short; tips of digits rounded, not expanded laterally; ulnar tubercles absent, ulnar fold narrow, low; inner palmar tubercle single, ovoid, outer palmar tubercle slightly ovoid; fingers moderately short, without lateral fringes; subarticular tubercles round; supernumerary tubercles distinct, few, ovoid, small; first finger slightly shorter than second, III $>$ IV $=$ II $>$ I; tips of digits rounded, lacking marginal grooves; tibia length $33 \%$ of SVL; tarsal fold absent; inner metatarsal ovoid 1.5 times longer than outer metatarsal tubercle; subarticular tubercles small, ovoid; supernumerary tubercles small, poorly defined; toes having lateral fringes, lacking basal webbing; relative length of toes IV $>$ III $>\mathrm{V}>$ II $>$ I, digital tips rounded lacking marginal grooves; foot length $42 \%$ of SVL.

Coloration of holotype in life.-Head dorsally reddish-brown, laterally reddish-brown with small yellow blotches, labial bar slightly darker; upper half of iris pale bronze, lower half dark brown; dorsal surface of body reddish brown with small yellow spots and some irregular brown blotches, narrow bronze middorsal stripe extending from cloaca to middle of body; belly pale bluish-gray with reddishbrown reticulations; dorsal surface of limbs similar to dorsal coloration, ventral surface reddish-brown with irregular gray blotches (Figure 2A, B).

Coloration of holotype in preservative.Dorsal and lateral surface of head and dorsum of body brown, ventral coloration similar to that in life (Figure 1).

Variation.-All specimens have a discontinuous middorsal, bronze stripe extending from cloaca anteriorly to the level of tympanum; in three specimens this stripe extends to the mid dorsum (MUBI 11147, 11152, 16083), while in one specimen (MUBI 11154) it extends sidewise to form a triangle. The ventral coloration is variable, especially the relative size of brown spots which are larger in four specimens (MUBI 11149-11150, 11153, 16069), intermediate in size in seven specimens (MUBI 11147-11148, $11151,11154,16068,16074,16083)$, and smaller in two specimens (MUBI 11152, 11159). One specimen (MUBI 11153) has minute yellow spots on the flanks.

Etymology.-The specific epithet mancoinca refers to the most important Inca of Vilcabamba, Manco Inca, who was the leader of the last Incan resistance in southeastern Peru.

Vocalization and reproduction.-Males call from bunch grasses in the humid puna, during the day from 10:00 to 16:00 hrs. We did not hear males calling during our evening and night surveys. The advertisement call of unvouchered males consist of three (68\% of recorded calls) or two (32\% of recorded calls) unpulsed notes resembling whistles, with dominant frequency $2400 \mathrm{~Hz}$ (range from 2250 to $2437 \mathrm{~Hz}$; Figure 3, Table 2). Calls with three notes appear to have slightly lower dominant frequencies (Table 2) at the first note, but the difference is not significant $(\mathrm{t}=1.25, \mathrm{df}=26, p=0.22)$. No frequency modulation occurs within or among calls. The calling rate was $0.115 \pm 0.006$ calls/second at a temperature of $13.3^{\circ} \mathrm{C}$. In all calls, the first note

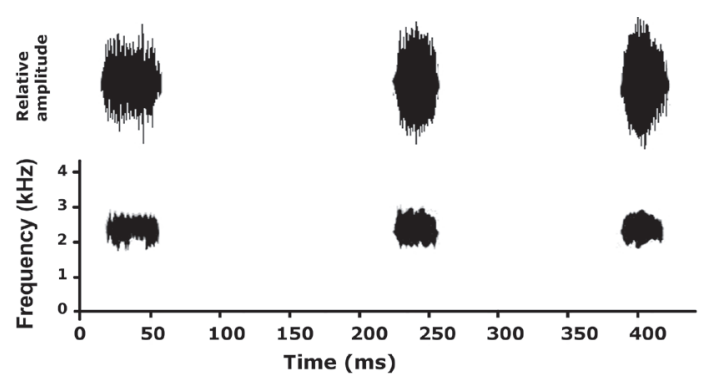

Figure 3. Advertisement call of Bryophryne mancoinca sp. nov. (unvouchered specimen) recorded at the type locality on 20 September $2015\left(\mathrm{~T}_{\text {air }}=\right.$ $\left.13.3^{\circ} \mathrm{C}\right)$. 
is longest, followed by the second note and, when present, the third note. The first note appears to be slightly longer in calls with two notes $(85.1 \pm 16.5 \mathrm{~ms}$, range $46.0-100.0 \mathrm{~ms}, N=$ 9) than in calls with three notes $(67.8 \pm 28.6 \mathrm{~ms}$, range $28-108 \mathrm{~ms}, N=19$ ), but the difference is not significant $(\mathrm{t}=2.02, \mathrm{df}=26, p=0.10)$. The second note is similar in duration in all calls $(\mathrm{t}=$ -0.69 , df $=26, p=0.49)$ and averages $30.4 \pm$ $13.0 \mathrm{~ms}$ (range $18.0-94.0 \mathrm{~ms}, N=28$ ), whereas the third note averages $27.9 \pm 5.6 \mathrm{~ms}$ (range $16.0-35.0 \mathrm{~ms}, N=19$ ).

\section{Distribution and natural history.-} Bryophryne mancoinca sp. nov. is known only from the type locality at elevations from 3519 to $3707 \mathrm{~m}$ a.s.1 (Figure 4). Specimens were collected during the dry season (September), under rocks, between moss and roots. This species inhabits the transition from the montane forest to

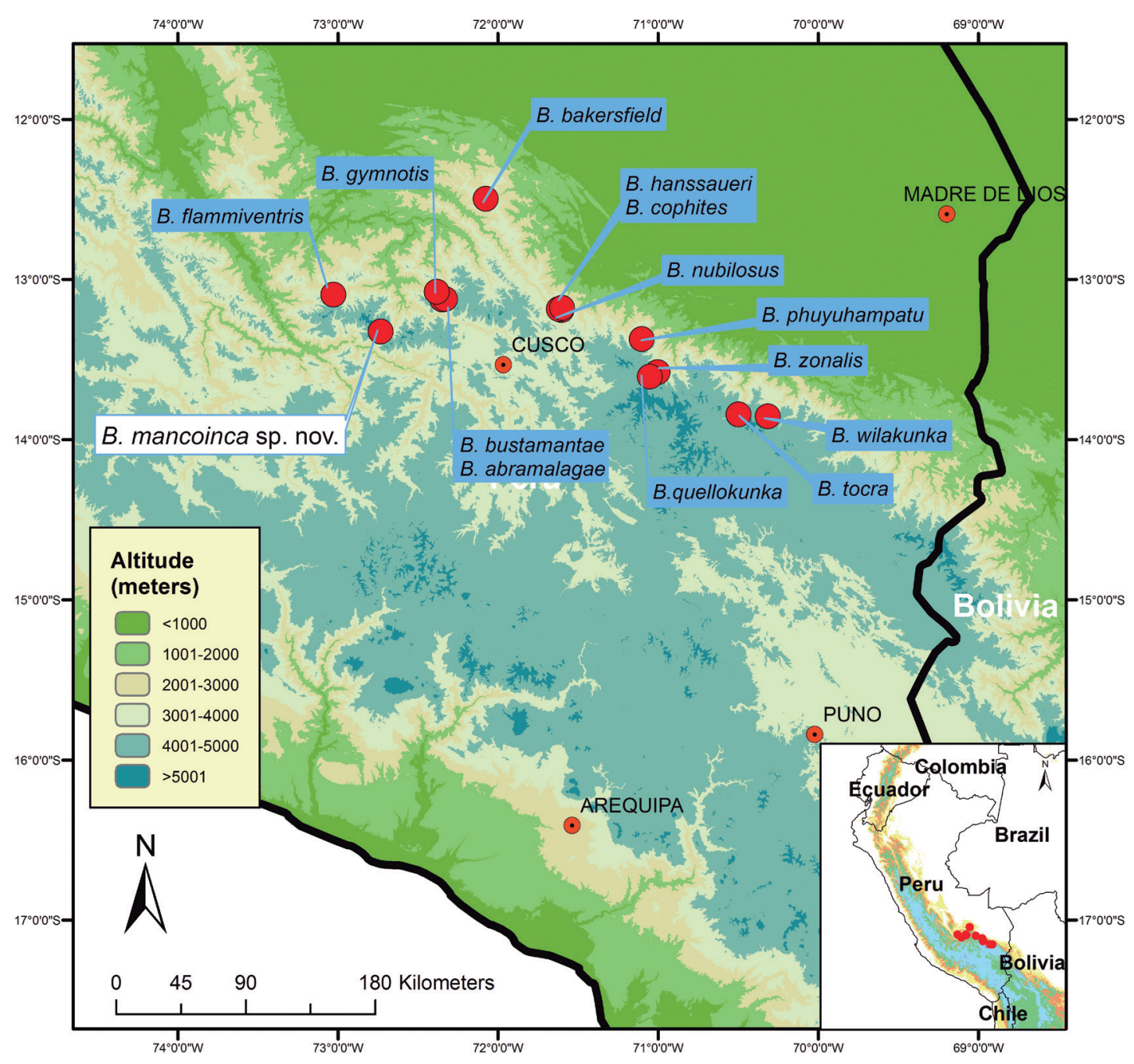

Figure 4. Map of Peru showing the type localities of the species of Bryophryne. 
the high Andean puna (Figure 5). Sympatric amphibian species include Gastrotheca excubitor Duellman and Fritts, 1972, Telmatobius sp., Psychrophrynella sp., Pleurodema marmoratum (Duméril and Bibron, 1840) and Rhinella spinulosa (Wiegmann, 1834).

\section{Discussion}

In recent years the number of species of Terrarana inhabiting the Peruvian Andes has increased significantly (Chaparro et al. 2007, 2015, Lehr and Catenazzi 2008, 2009, 2010,

Table 2. Characteristics of the advertisement call of Bryophryne mancoinca sp. nov. based on recordings of unvouchered specimens. Values are given as mean $\pm \mathrm{SD}$.

\begin{tabular}{|c|c|c|c|c|}
\hline Trait & $N$ & Duration (ms) & Interval (ms) & Dominant Frequency $(\mathrm{Hz})$ \\
\hline \multicolumn{5}{|l|}{ CALL TYPE } \\
\hline Two notes & 9 & $259.8 \pm 21.1$ & $8150.1 \pm 4572.1$ & $2437.5 \pm 0.0$ \\
\hline Three notes & 19 & $398.6 \pm 45.9$ & $9699.1 \pm 4807.4$ & $2407.9 \pm 70.2$ \\
\hline \multicolumn{5}{|l|}{ NOTES } \\
\hline First note & 28 & $73.3 \pm 26.3$ & - & $2417 \pm 59.1$ \\
\hline Second note & 28 & $30.4 \pm 13.0$ & $145.5 \pm 16.4$ & $2424.1 \pm 49.2$ \\
\hline Third note & 19 & $27.9 \pm 5.6$ & $134.5 \pm 8.0$ & $2437.5 \pm 0.0$ \\
\hline
\end{tabular}

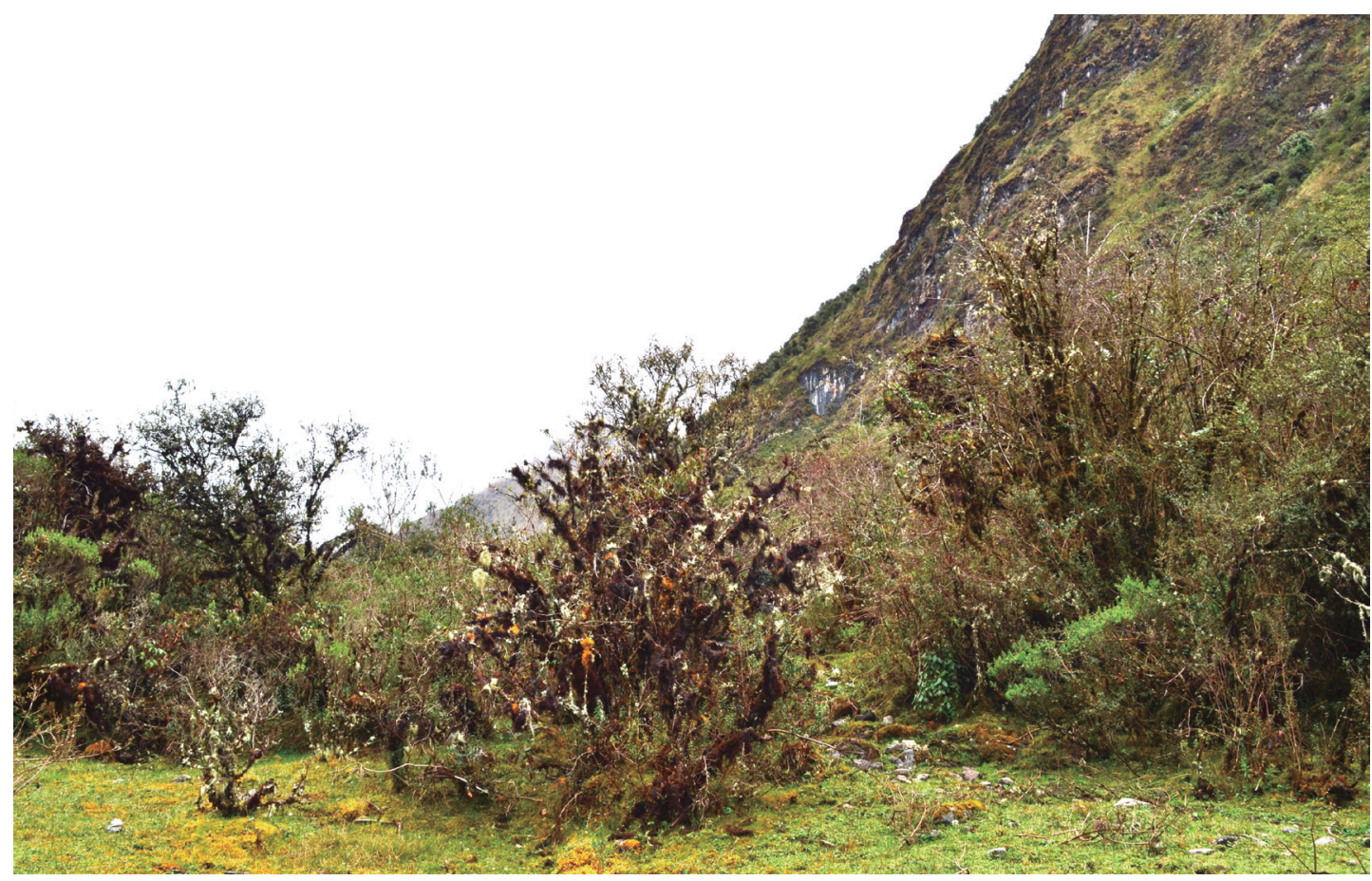

Figure 5. Type locality and habitat of Bryophryne mancoinca sp. nov. Photo by Alex Ttito (19 September 2015). 
Lehr et al. 2012, Lehr and Oróz 2012; Mamani and Malqui 2014, Chavez et al. 2015, Catenazzi and Ttito 2016), contributing to high rates of species discovery for Peru (Catenazzi 2015). Many of these recent discoveries were made in previously unexplored areas, highlighting the importance of filling survey gaps in the Andes. The genus Bryophryne is an extreme example of these discovery patterns, because 13 of 14 known species have been discovered over the past 10 years, and because all species are highly endemic with their known geographic distributions restricted to their type localities and immediate surroundings. We therefore expect that additional species will be discovered in the future as researchers explore isolated or remote mountain ranges that are not easily accessible by road.

Bryophryne mancoinca sp. nov. shares the presence of tympanic membrane and annulus, vocal sac and slits in males, and (as far as we know) emission of advertisement calls with only two other congeneric species (B. flammiventris and $B$. gymnotis). Furthermore, these three species are distributed in valleys of the Cordillera de Vilcabamba, whereas the other known Bryophryne inhabit different ranges of the Cordillera de Vilcanota massif. We hypothesize that B. flammiventris, B. gymnotis, and $B$. mancoinca sp. nov. might represent a distinct, and currently unrecognized clade from Bryophryne, with the main distinguishing feature being the presence of vocal sac and slits, tympanic membrane and annulus, and advertisement call. Members of this clade would be restricted to the upper watershed of the Cordillera de Vilcabamba south of the Apurimac canyon, without overlap with the known geographic distributions of other Bryophryne species. Future molecular analyses should test this hypothesis, and are likely to provide insight into diversification patterns in these groups of high-elevation Holoadeninae.

Montane forest frogs in southern Peru have been negatively affected by epizootics of chytridiomycosis, caused by the fungus Batrachochytrium dendrobatidis Longcore, Pessier and Nichols, 1999 (Catenazzi et al. 2011, 2014). This fungus has been reported in a Pleurodema marmoratum (Duméril and Bibron, 1840) from the Cordillera de Vilcabamba in 2008 (Catenazzi et al. 2011), and has likely caused population declines and local extinctions of several taxa, but appears to be less of a threat for terrestrial-breeding species such as Bryophryne than for aquatic-breeding species (Catenazzi et al. 2011). However, the population status of Bryophryne mancoinca sp. nov. and its vulnerability to chytridiomycosis are presently unknown.

\section{Acknowledgments}

We thank personnel from the collection of amphibians and reptiles of the Museo de Biodiversidad del Perú (MUBI), for providing material for this study. We are grateful to the Center for Conservation, Education and Sustainability of the Smithsonian Conservation Biology Institute for providing laboratory equipment. We thank I. De la Riva and anonymous reviewers for their valuable comments and suggestions on the manuscript. We are grateful to Janalee Caldwell for reviewing our manuscript. Collecting permits in Peru were issued by SERNANP-Machu Picchu (054-2012-SERNANP-JEF). This work was partially supported by the Programa Incentivo para la Publicación Efectiva de Artículos Científicos en Revistas Indizadas 2015 (RDE 159-2015-FONDECYT-DE, P. I. L. Mamani) and 2016 (RDE 036, 20.04.2016, P. I. J. C. Chaparro) del Consejo Nacional de Ciencia, Tecnología e Innovación Tecnológica de Perú [CONCYTEC-FONDECYT (Cienciactiva)]. All specimens described herein have been deposited in the Museo de Biodiversidad del Perú (MUBI), which is recognized by the Resolución de Dirección General No 024-2017-SERFOR/ DGGSPFFS. 


\section{References}

Catenazzi, A. 2015. State of the world's amphibians. Annual Review of Environment and Resources 40: 91-119.

Catenazzi, A. and A. Ttito. 2016. A new species of Psychrophrynella (Amphibia, Anura, Craugastoridae) from the humid montane forests of Cusco, eastern slopes of the Peruvian Andes. PeerJ 4: e1807.

Catenazzi, A., E. Lehr, and V. T. Vredenburg. 2014. Thermal physiology, disease and amphibian declines in the eastern slopes of the Andes. Conservation Biology 28: 509-517.

Catenazzi, A., E. Lehr, L. O. Rodriguez, and V. T. Vredenburg. 2011. Batrachochytrium dendrobatidis and the collapse of anuran species richness and abundance in the upper Manu National Park, southeastern Peru. Conservation Biology 25: 382-391.

Catenazzi, A., A. Ttito, M. I. Díaz, and A. Shepack. 2017. Bryophryne phuyuhampatu sp. n. (Amphibia, Anura, Craugastoridae), a new species of Cusco Andes frog from the cloud forest of the eastern slopes of the Peruvian Andes. ZooKeys 685: 65-81.

Chaparro, J. C., J. M. Padial, R. C. Gutiérrez, and I. De la Riva. 2015. A new species of Andean frog of the genus Bryophryne from southern Peru (Anura: Craugastoridae) and its phylogenetic position, with notes on the diversity of the genus. Zootaxa 3994: 94-108.

Chaparro, J.C., I. De la Riva, J. M. Padial, J. A. Ochoa, and E. Lehr. 2007. A new species of Phrynopus from Departamento Cusco, southern Peru (Anura: Brachycephalidae). Zootaxa 1618: 61-68.

Chávez, G., R. Santa-Cruz, D. Rodriguez, and E. Lehr. 2015. Two new species of frogs of the genus Phrynopus (Anura: Terrarana: Craugastoridae) from the Peruvian Andes. Amphibian \& Reptile Conservation 9 [Special Section]: 15-25.

De la Riva, I., J. C. Chaparro, S. Castroviejo-Fisher and J. M. Padial. 2017. Underestimated anuran radiations in the high Andes: five new species and a new genus of Holoadeninae, and their phylogenetic relationships (Anura: Craugastoridae). Zoological Journal of the Linnean Society 40: 1-44.

Duellman, W. E. and E. Lehr. 2009. Terrestrial-Breeding Frogs (Strabomantidae) in Peru. Münster. Natur- und Tier-Verlag, Naturwissenschaft. 382 pp.

Hedges, S. B., W. E. Duellman, and M. P. Heinicke. 2008. New World direct developing frogs (Anura: Terrarana): molecular phylogeny, classification, biogeography, and conservation. Zootaxa 1737: 1-182.
Heinicke, M. P., A. R. Lemmon, E. M. Lemmon, K. McGrath, and S. B. Hedges. 2017. Phylogenomic support for evolutionary relationships of New World Direct-developing Frogs (Anura: Terraranae). Molecular Phylogenetics and Evolution 118: 145-155.

Lehr, E. and A. Catenazzi. 2008. A new species of Bryophryne (Anura: Strabomantidae) from southern Peru. Zootaxa, 1784, 1-10.

Lehr, E. and A. Catenazzi. 2009. Three new species of Bryophryne (Anura: Strabomantidae) from the region of Cusco, Peru. South American Journal of Herpetology 4: $125-138$.

Lehr, E. and and A. Catenazzi. 2010. Two new species of Bryophryne (Anura: Strabomantidae) from high elevations in southern Peru (Region of Cusco). Herpetologica 66: 308-319.

Lehr, E. and A. Oróz. 2012. Two new species of Phrynopus (Anura: Strabomantidae) from the Cordillera de Carpish in central Peru (Departamento de Huanuco). Zootaxa 3512: 53-63.

Lehr, E., J. Moravec, and J. C. Cusi. 2012. Two new species of Phrynopus (Anura, Strabomantidae) from high elevations in the Yanachaga-Chemillén National park in Peru (Departamento de Pasco). ZooKeys 235: 51-71.

Lynch, J. D. and W. E. Duellman. 1997. Frogs of the genus Eleutherodactylus in western Ecuador: systematics, ecology, and biogeography. Special Publication of Natural History Museum, University of Kansas 23: $1-236$.

Mamani, L. and S. Malqui. 2014. A new species of Phrynopus (Anura: Craugastoridae) from the central Peruvian Andes. Zootaxa 3838: 207-214.

Padial, J. M., T. Grant, and D. R. Frost. 2014. Molecular systematics of terraranas (Anura: Brachycephaloidea) with an assessment of the effects of alignment and optimality criteria. Zootaxa 3825: 1-132.

Padial, J. M., J C. Chaparro, S. Castroviejo-Fisher, J. M. Guayasamin, E. Lehr, A. J. Delgado, M. Vaira, M. Teixeira Jr., R. Aguayo and I. De la Riva. 2012. A revision of species diversity in the Neotropical genus Oreobates (Anura: Strabomantidae), with the description of three new species from the Amazonian slopes of the Andes, and the proposal of candidate species. American Museum Novitates 3752: 1-55.

Rodriguez, L. O. and A. Catenazzi. 2017. Four new species of terrestrial-breeding frogs of the genus Phrynopus (Anura: Terrarana: Craugastoridae) from the Río Abiseo National Park, Peru. Zootaxa 4273: 381-406.

Editor: Ignacio De la Riva 
Appendix I. Type specimens examined.

Bryophryne bakersfield: PERU: Departamento Cusco, Provincia La Convención, Distrito Echarate, Roquerio Lorohuachana, 3620 m a.s.I. (12²9'43.8” S, 7204'35.9” W), MUBI 7972 (holotype).

Bryophryne bustamantei: PERU: Departamento Cusco, Provincia La Convención, Distrito Huayopata, Canchayoc, near Abra de Málaga, 3663 m a.s.I. (1307'16.2" S, 72¹9’53" W), MUBI 6019 (holotype); MUSM 24537-24538.

Bryophryne cophites: PERU: Departamento Cusco, Provincia Paucartambo, Distrito Paucartambo, Abra Acjanaco: KU 138884 (holotype); N slope Abra Acanaco (Acjanaco), 27 km NNE Paucartambo, 3450 m a.s.l.: KU 138885-138908, 138911-138915 (all paratypes); 2 km NE of Abra Acanaco (Acjanaco), $3280 \mathrm{~m}$ a.s.I.: MHNG 2698.24, $5.5 \mathrm{~km} \mathrm{~N}$ of Abra Acanacu (Acjanaco), $3523 \mathrm{~m}$ a.s.I.: MUSM 27895, Tres Cruces, $8.5 \mathrm{~km} \mathrm{~N}$ of Abra Acanaco (Acjanaco), 3590 m a.s.I.: MUSM 20855-20856, 26283-26284, 26264, 26266-26267, 26313, 26315, 27896, 3041430417, Pillco Grande, 3865 m a.s.I., near border of Manu NP: CORBIDI 11919.

Bryophryne gymnotis: PERU: Departamento Cusco, Provincia La Convención, Distrito Huayopata, San Luis, near Abra de Málaga, MUBI 14315-14319, 1 km east of San Luis at elevations of 3272-3354 m a.s.I.: MUSM 24543 (holotype), MHNG 2710.28, 2710.29, MTD 46860-46864, 47288, 47291-47292, 47297, MUSM 24541-24542, 24544-24545, 24546-24556, MVZ 258407-258410 (all paratypes), MUBI 14315-14319 (paratopotype) 13²'12" S, $72^{\circ} 22^{\prime} 50^{\prime \prime} \mathrm{W}, 3539 \mathrm{~m}$ a.s.l.

Bryophryne hanssaueri: PERU: CUSCO: Provincia Paucartambo, Distrito Kosñipata: Acjanaco, Manu National Park, 3266 m a.s.I.: MUSM 27567 (holotype); from near Acjanaco, Manu National Park at elevations of 3280-3430 m a.s.I.: MHNG 2698.25, MTD 46865-46866, 46887-46889, MUSM 24557, 27568-27569, 27607-27611, MVZ 258411-25813 (all paratypes).

Bryophryne nubilosus: PERU: CUSCO: Provincia Paucartambo: DistritoKosñipata, 500 m NE of Esperanza, 2712

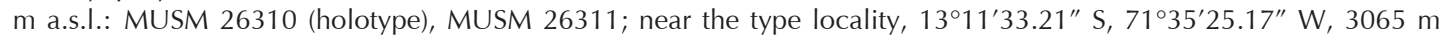
a.s.I.: MTD 47294; near Hito Pillahuata, 2600 m a.s.I.: MUSM 20970; Quebrada Toqoruyoc, 3097 m a.s.I.: MUSM

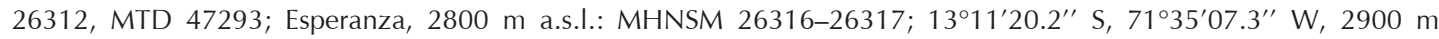
a.s.I.: MUSM 24539-24540.

Bryophryne phuyuhampatu: PERU: CUSCO: Provincia Paucartambo, Distrito Paucartambo, Área de Conservación Privada (ACP) Ukumari Llaqta, Quispillomayo valley, 2795-2850 m a.s.I., CORBIDI 18226 (holotype), CORBIDI 18224-18225, 18227-18228 and MUBI 14654-14655, 14665.

Bryophryne zonalis: PERU: CUSCO: Provincia Quispicanchis, Distrito Marcapata, Kusillochayoc at $3129 \mathrm{~m}$ a.s.I.: MUSM 27570 (holotype), MTD 46867, 46869-46870, MUSM 27572, 27574-27575, 27861, MVZ 258414 (all paratpyes); at Puente Coline, 3285 m a.s.I.: MVZ 258415 (paratype).

Noblella madreselva: PERU: CUSCO: Provincia La Convención, Madre Selva (Santa Ana), CORBIDI 1576915770 .

Noblella pygmaea: PERU: CUSCO: Provincia Paucartambo, Kosñipata, MHNG 2725.29-30, MUSM 2453524536, 26306-26307, 26318-26320, 30423-30424, 30453-30454, MTD 47286-47287.

Psychrophrynella bagrecito: PERU: CUSCO: Quispicanchis: Marcapata, Río Marcapata, below Marcapata, ca. 2740 m, KU 196512 (holotype), KU 196513-196518, 196520-196521, 196523-196525 (all paratypes); La Convención: Hacienda Huyro between Huayopata and Quillabamba, 1830 m a.s.l., KU 196527-196528.

Psychrophrynella chirihampatu: PERU: CUSCO: Área de Conservación Privada (ACP) Ukumari Llaqta, Comunidad Campesina de Japu: CORBIDI 16495 (holotype), CORBIDI 16496-16509, and MUBI 14658, 14661, 14662, 14666146672 (all paratypes).

Psychrophrynella usurpator: PERU: CUSCO: Provincia Paucartambo, Kosñipata, MUSM 20011, 20873-20881, 20896-20913, 20925-20933, 20946-20947, 20955-20957, 21012-21018, 26272-26273, 26278-26279, 26308, 27592, 27906, 27950, 28033-28047, 30303, 30305, 30396-30400, 30405-30409, 30471-30474.

Phrynopus chaparroi: PERU: Departamento Junin, Provincia Concepcion, Distrito Comas, Canchapalca, $4490 \mathrm{~m}$

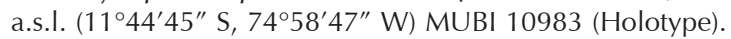

Phrynopus miroslawae: PERU: Departamento Pasco, Provincia Oxapampa, Distrito Huancabamba,Type locality: Santa Barbara,3363 m a.s.I., (10²0'13.8' S, 75³8'47.3" W), MUBI 6469 (holotype).

Phrynopus nicoleae: PERU: Departamento Pasco, Provincia Oxapampa, Distrito Huancabamba, Type locality: Santa Barbara, 3589 m a.s.I., (10²0'36.3" S, 75³8'17.9" W), MUBI 6441 (holotype). 